\title{
Growth of Regenerating Goldfish Axons Is Inhibited by Rat Oligodendrocytes and CNS Myelin but Not by Goldfish Optic Nerve Tract Oligodendrocytelike Cells and Fish CNS Myelin
}

\author{
Martin Bastmeyer, ${ }^{1}$ Matthias Beckmann,, ${ }^{1}$ Martin E. Schwab, ${ }^{2}$ and Claudia A. O. Stuermer ${ }^{1}$ \\ 'Friedrich-Miescher-Laboratorium der Max-Planck-Gesellschaft, D-7400- Tübingen, Germany, and ${ }^{2}$ Institut für \\ Hirnforschung, Universität Zürich, CH-8029, Zürich, Switzerland
}

\begin{abstract}
Encounters of regenerating goldfish retinal axons with oligodendrocytes and CNS myelin of mammals and fish were monitored in in vitro assays. Upon contact with highly branched rat oligodendrocytes, goldfish axons collapsed or grew around but never crossed these cells. However, in the presence of the antibody IN-1 against the oligodendrocyteassociated growth-inhibitory proteins, axons did grow over highly branched oligodendrocytes. In contrast to the mammalian oligodendrocytes, goldfish optic nerve/tract-derived oligodendrocytelike cells allowed the growth of axons across their surface and even along their processes. The fish growth cones avoided entering the region of rat CNS myelin applied to polylysine/laminin-coated coverslips or failed to elongate on this substrate. They were, however, able to pass over CNS myelin of fish. When exposed to rat CNS myelin as the sole substrate, axonal outgrowth from fish retinal explants was inhibited almost entirely. However, outgrowth on fish CNS myelin was substantial, but many more axons extended on fish or rat brain membranes that were depleted of myelin. Thus, goldfish retinal axons are sensitive to the axon-growthinhibiting cell-surface molecules of mammalian oligodendrocytes as well as CNS myelin. Fish optic nerve oligodendrocytelike cells and fish CNS myelin lack these inhibitory properties and are growth permissive. These in vitro experiments suggest that the success of axonal regeneration in the fish optic nerve is causally related to the presence of growth-permissive properties and to the absence of growth inhibitors on fish optic nerve/tract oligodendrocytelike cells.
\end{abstract}

The majority of neurons in the CNS of mammals and birds exhibit a very limited capacity for spontaneous axonal regeneration. In the optic nerve, as in other regions of the CNS, axotomy is followed by cell death and by a minimal regenerative response of the surviving ganglion cells. Injured axons in the PNS of these species, however, regrow more successfully. The situation is quite different in lower vertebrates. In fish and amphibians, retinal axons regenerate readily after optic nerve transection and reestablish appropriate connections to their targets (reviewed in Gaze, 1970).

\footnotetext{
Keceived Mar. 27, 1990; revised Oct. 17, 1990; accepted Oct. 24, 1990.

We wish to thank Anette Habring-Müller for her excellent technical assistance and Paul Whitington for corrections on the manuscript. This work was supported by Deutsche Forschungsgemeinschaft Grant Stu 112/4 to C.A.O.S. and a grant from the Swiss National Science Foundation to M.E.S.

Correspondence should be addressed to M. Bastmeyer, University of Konstanz, Faculty of Biology, D-7750 Konstanz, Germany.

Copyright (c) 1991 Society for Neuroscience 0270-6474/91/1 10626-15\$03.00/0
}

Recent evidence suggests that the failure of successful axonal regeneration in the mammalian CNS is not simply a property of the neuron, but also depends on the environment surrounding the injured axons. After optic nerve section, rat retinal ganglion cells reextend their axons over considerable distances if the optic nerve is removed and replaced experimentally by a peripheral nerve graft (So and Aguayo, 1985). Contact with glial cells of the peripheral nerve and soluble factors produced in this nerve obviously reduces the lesion-induced death rate of rat ganglion cells and promotes the elongation of regenerative axonal sprouts (Thanos et al., 1989).

The mammalian optic nerve contains, among other glial cells, oligodendrocytes, and these glial cells and their product, the CNS myelin, possess nonpermissive properties for neurite growth (Schwab and Caroni, 1988). Two cell-surface-associated proteins of 35 and $250 \mathrm{kDa}$ (Caroni and Schwab, 1988a) are responsible for these properties. Monoclonal antibodies against these 2 proteins can neutralize the nonpermissive properties of the cells (Caroni and Schwab, 1988b). These proteins are not detectable in peripheral nerves, which are myelinated by Schwann cells instead of oligodendrocytes. Schwann cells have been shown to support the growth of various types of axons in vivo and in vitro (Kleitman et al., 1988).

Retinal axons in goldfish regenerate through the optic nerve despite the fact that the fish nerve has oligodendrocytes that myelinate the axons (Jeserich and Waehneldt, 1986; Wolburg and Bouzehouane, 1986). The success of axonal regeneration in fish probably depends on a variety of factors. The ganglion cells in fish may differ in their intrinsic properties (Stuermer, 1991). They may not be sensitive to negative influences in their environment or be able to overcome them, or their environment may have components that stimulate axonal growth. Biochemical analyses have shown that the inhibitory proteins of mammalian oligodendrocytes and their myelin are not detectable in fish (Caroni and Schwab, 1988a), leading to the prediction that fish oligodendrocytes and their myelin should not inhibit the regrowth of retinal axons.

The isolation of goldfish optic nerve oligodendrocytelike cells and their maintenance in culture has recently been accomplished (Bastmeyer et al., 1989), allowing coculture of goldfish axons and oligodendrocytelike cells to test the predictions stated above. On the other hand, cocultures of goldfish retinal axons and rat oligodendrocytes could test whether fish axons are sensitive to the growth-inhibiting properties of mammalian oligodendrocytes. The present study has monitored the encounters of goldfish retinal axons with fish or mammalian glial cells using timelapse videomicroscopy. The substrate properties of myelin, one 
of the products of oligodendrocytes, were tested in a quantitative growth assay and in an in vitro choice assay. We found that rat CNS myelin and oligodendrocytes are inhibitory substrates for the growth of goldfish retinal axons, indicating that goldfish retinal axons are sensitive to the rat neurite growth inhibitor. Fish optic nerve oligodendrocytelike cells or fish CNS myelin, on the other hand, are permissive substrates for axonal growth.

Parts of these results have been presented as abstracts (Bastmeyer et al., 1988, 1990; Beckmann et al., 1989).

\section{Materials and Methods}

Glial cell cultures from rat optic nerves. Optic nerves from 9-12-d-old rats, anesthesized by ether, were dissected, freed from the meninges in Hank's medium, cut into small pieces, and incubated twice in $0.25 \%$ trypsin (Merck) and $0.03 \%$ collagenase (Worthington) in Hank's medium for $25 \mathrm{~min}$ at $37^{\circ} \mathrm{C}$. Cells were dissociated by trituration with a pipette, rinsed in Dulbecco's minimal essential medium (DMEM) supplemented with $10 \%$ fetal calf serum (FCS), and plated on polylysine/ laminin-coated coverslips at a density of $25,000-30,000$ cells per coverslip. They were cultured in DMEM with $10 \% \mathrm{FCS}$ at $37^{\circ} \mathrm{C}$ for at least $10 \mathrm{~d}$ until the goldfish retina was explanted onto the coverslip carrying these cells.

Glial cell cultures from the goldfish optic nerve/tract. Glial cells from goldfish optic nerves were obtained as described earlier (Bastmeyer et al., 1989). In brief, small pieces of optic nerves and tracts (2-3 weeks after optic nerve section) were explanted onto polylysine/laminin-coated coverslips and kept in modified Leibowitz medium [L-15 supplemented with $10 \% \mathrm{FCS}, 0.4 \%$ methyl cellulose (Dow), and $50 \mu \mathrm{g} / \mathrm{ml}$ gentamycin (Gibco)] at $22^{\circ} \mathrm{C}$. Glial cells emigrate from these pieces, multiply, and survive for several weeks. All experiments were performed with 2-3week-old goldfish glial cell cultures.

Glial cell cultures from juvenile zebrafish brains. Brains from juvenile zebrafish (10-20 d old) were collected in Hank's medium, divided into small pieces, and incubated in $0.03 \%$ collagenase (Worthington) and $0.1 \%$ dispase (Boehringer) in Hank's medium for $25 \mathrm{~min}$ at $27^{\circ} \mathrm{C}$. The enzyme-treated material was rinsed in L-15, and the cells were pelleted with low-speed centrifugation, plated onto polylysine/laminin-coated coverslips at a density of 30,000-40,000 cells per coverslip, and grown in modified $\mathrm{L}-15$ at $27^{\circ} \mathrm{C}$.

Coculture of goldfish retinal axons and glial cells. Goldfish retinal explants were prepared as described in Vielmetter and Stuermer (1989). In brief, eyes were removed from adult goldtish that had received a conditioning optic nerve lesion 14-17 d prior to preparation. The retina was isolated and attached (photoreceptor layer down) to a nylon filter (Hybond, Amersham). Filter and retina were cut into 300- $\mu \mathrm{m}$-wide segments with a Mcllwain tissue chopper, and the segments were explanted, ganglion cell layer down, onto the coverslips on which the glial cells reside. To keep the retina in contact with the substrate, small metal blocks were placed onto the ends of the filter to which the retina was attached. The coverslips carrying the cocultures were transferred onto the bottom of petriperm dishes (Heraeus) and incubated in modified L15 at $23^{\circ} \mathrm{C}$ in a humidified chamber.

The culture conditions optimal for fish cells and axons were of course not quite adequate for the rat glial cells. During the $1-2-d$ period over which the time-lapse videorecordings were made, first a few and then increasingly more cells died. We only monitored encounters of axons with glial cells that appeared viable and healthy. The oligodendrocytes considered here exhibited active movements of their membranous processes, particularly as axons approached them, indicating that their typical cellular responses were not significantly impaired at lower temperatures in L-15. Most important for these experiments, the expression of their inhibitory cell-surface proteins was obviously maintained. This was inferred from the dramatic reaction of the axons upon contact with differentiated oligodendrocytes.

Identification of rat oligodendrocytes. Oligodendrocytes of rats were identified with the monoclonal antibodies $(\mathrm{Mab}) \mathrm{O}_{1}$ or $\mathrm{O}_{4}$ directed against oligodendrocyte-specific gangliosides (Sommer and Schachmer, 1981). In 2 control experiments, the monoclonal antibody against galactocerebroside (GalC; Ranscht et al., 1982) was used to identify rat oligodendrocytes. Prior to the addition of the goldfish retinal explants, the living glial cells were exposed to $\mathrm{O}_{1}$ or $\mathrm{O}_{4}$ antibodies (hybridoma supernatant diluted 1:2 in L-15) for $30 \mathrm{~min}$, washed in L-15, and then incubated with the secondary antibody [rhodamine isothiocyanate (RITC)-coupled goat anti-mouse antibodies (Dianova), diluted 1:100 in L-15].

These treatments and the bound antibody complex apparently did not interfere with the expression of the inhibitory proteins in living cells as judged by the above-mentioned criteria. Thus, we are confident that the growth cone reactions observed here are evoked by a specific influence of the cells on the goldfish growth cones and are not culture artifacts. This is supported by the finding that growth cone collapse is typically induced by 1 type of cell, the highly branched $\mathrm{O}_{1}$-positive oligodendrocyte, and not by $\mathrm{O}_{1}$-negative cells or by goldfish glial cells.

In one experiment, the monoclonal antibody IN-1 (Caroni and Schwab, $1988 \mathrm{~b}$ ) was added to cocultures of rat oligodendrocytes and retinal axons. This antibody is directed against the 35 - and $250-\mathrm{kDa}$ inhibitory cell-surface proteins of oligodendrocytes and has been reported to neutralize the growth-inhibiting properties that mammalian CNS myelin and oligodendrocytes exert on neurites upon contact (Caroni and Schwab, $1988 b$ ). The $1 \mathrm{~N}-\mathrm{l}$-producing hybridomas were raised in DMEM with FCS. This medium interferes with goldfish axonal growth when added to our coculture system. Therefore, the IN-1-hybridoma supernatant was dialyzed against L-15 overnight, mixed $1: 1$ with modified L-15, and used as culture medium after the addition of the goldfish retinal explants.

Identification of goldfish and zebrafish oligodendrocytes. As reported earlier (Bastmeyer et al., 1989), most of the goldfish optic nerve glial cells in 2-3-week-old cultures are recognized by $\mathrm{Mab} \mathrm{O}_{4}$, and this was confirmed throughout all experiments, past and present. However, the earlier result that fish glial cells are also positive for the antibody $\mathrm{O}_{1}$, specific for differentiated oligodendrocytes in mammals, was not supported in our more recent experiments. Our recent results were gained with antibodies from the $\mathrm{O}_{1}$ - and $\mathrm{O}_{4}$-producing cell lines (kindly provided by $M$. Schachner) and which were propagated and subcloned in our laboratory. The $O_{1}$ antibodies of these cell lines do not bind to goldfish optic nerve/tract glial cells, whereas the $\mathrm{O}_{4}$ antibodies do. Both $\mathrm{Mab}_{1}$ and $\mathrm{Mab}_{4}$ of these cell lines stain rat oligodendrocytes.

The other marker for the identification of fish oligodendrocytes is the monoclonal antibody 6D2 (kindly provided by G. Jeserich). This antibody is directed against 2 trout CNS myelin proteins, IP1 and IP2 (Jeserich et al., 1990). It recognizes differentiated trout oligodendrocytes in vitro (Jeserich and Rauen, 1990), and in sections of trout, goldfish, and zebrafish brains, it stains myelinated CNS fiber tracts.

Staining with $\mathrm{Mab} \mathrm{O}_{4}$ was performed by treating the living cells with hybridoma supernatant (diluted 1:3 in L-15) for $30 \mathrm{~min}$. The cells wcre washed 2 times in L-15 and fixed with methanol $\left(-20^{\circ} \mathrm{C}, 5 \mathrm{~min}\right)$ and formaldehyde ( $2 \%$ in PBS, $5 \mathrm{~min}$ ). After 3 washes in PBS, they were incubated with RITC-coupled goat anti-mouse antibodies (Dianova) diluted 1:100 in PBS for $1 \mathrm{hr}$. Staining with Mab 6D2 was performed by treating either the living or the fixed cells with the antibody (hybridoma supernatant diluted 1:3 in either L-15 or PBS) and the secondary RITC-coupled antibody (see above). For double-labeling experiments with an antiserum against glial fibrillary acidic protein (GFAP) and oligodendrocyte markers, the living cells were treated with $\mathrm{MabO}_{4}$ or $6 \mathrm{D} 2$ and fixed as described above. They were subsequently incubated with a polyclonal rabbit antiserum against goldfish GFAP (Nona et al., 1989; diluted 1:1000 in PBS) for $1 \mathrm{hr}$. The secondary antibodies [RITCcoupled goat anti-mouse and flourescein isothiocyanate (FITC)-coupled goat anti-rabbit antibodies, diluted 1:200 in PBS] were applicd simultaneously for $1 \mathrm{hr}$ at $37^{\circ} \mathrm{C}$.

In one set of experiments, cells were double labeled with $\mathrm{Mab} \mathrm{O}_{4}$ (mouse IgM) and 6D2 (mouse IgG) by using chain-specific secondary antibodies. The living cells were treated with the $\mathrm{O}_{4}$ antibody and fixed as described. They were subsequently incubated with RITC-coupled $\mu$-chain-specific goat anti-mouse antibodies (Dianova) diluted $1: 100$ in PBS for $1 \mathrm{hr}$, washed, and then exposed to the 6D2 antibody (hybridoma supernatant diluted 1:3 in PBS) for $1 \mathrm{hr}$. After 3 washes in PBS, the cells were incubated with FITC-coupled $\gamma$-chain-specific goat anti-mouse antibodies (Dianova) diluted 1:200 in PBS for $1 \mathrm{hr}$. In control experiments, cells were treated with $\mathrm{Mab} \mathrm{O}_{4}$ alone to test the specificity of the secondary antibody. These cells did not react with the $\gamma$-chainspecific secondary antibodies.

The procedures for identifying zebrafish oligodendrocytes with Mab $\mathrm{O}_{4}$ and $6 \mathrm{D} 2$ were identical to those described for goldfish oligodendrocytes. In 2 experiments, a monoclonal anti-GalC antibody (Ranscht et al., 1982) was used to label the zebrafish oligodendrocytes.

Preparation of rat and fish CNS myelin and membranes. Spinal cords 

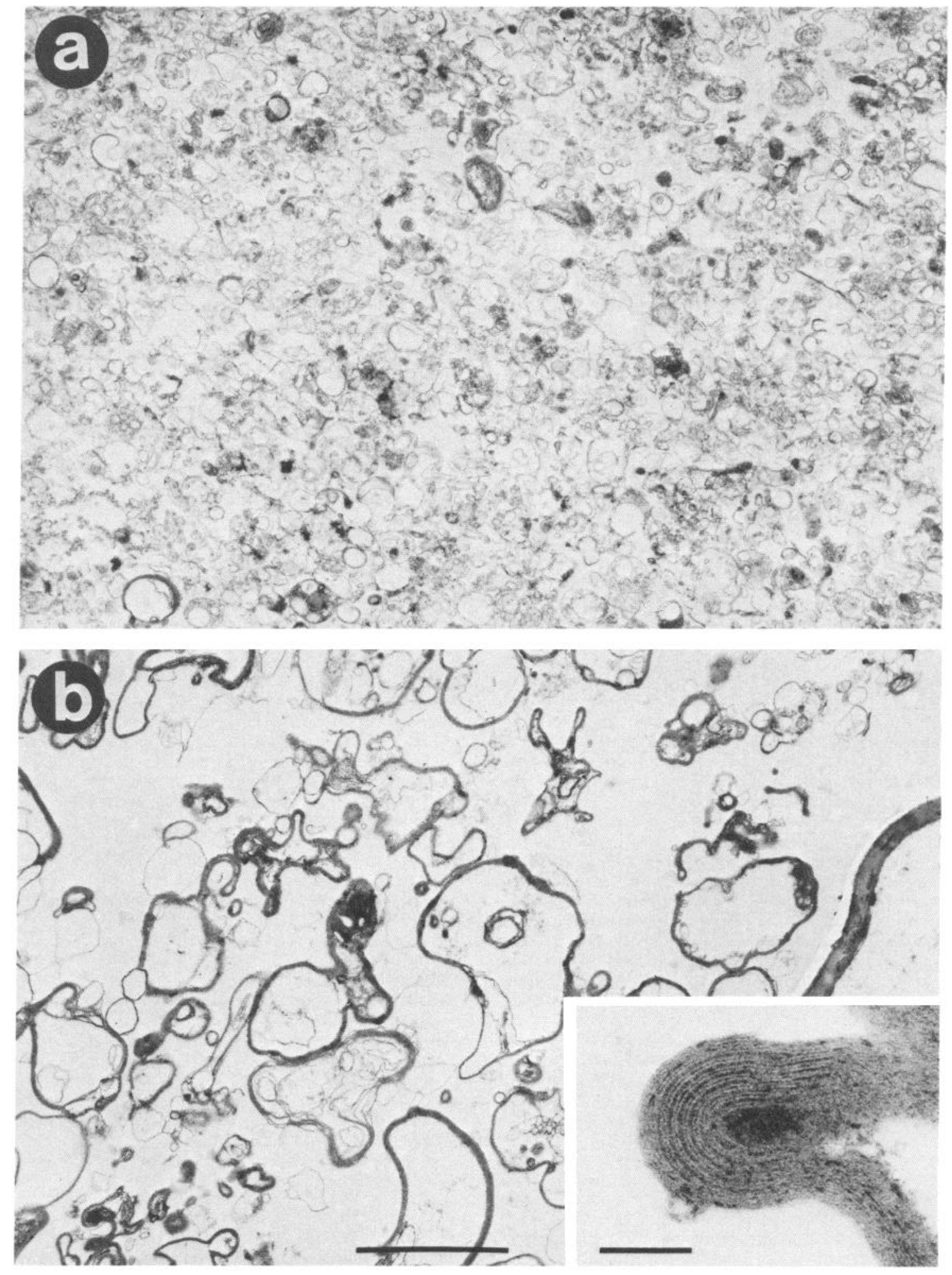

Figure 1. Electron micrographs of the membrane- $(a)$ and myelin-enriched $(b)$ fractions obtained from a sucrose step gradient centrifugation of goldfish tectum homogenates. Inset in $b$ is a higher magnification showing myelin lamellae, typical for the irregularly formed features in $b$. Scale bars: $b, 2 \mu \mathrm{m}$ for $a$ and $b$; inset, $0.1 \mu \mathrm{m}$.

and the white matter of rat brains ( 3 months old) were dissected in phosphate-buffered saline (PBS) and homogenized in homogenization (HS) buffer composed of $10 \mathrm{~mm}$ Tris- $\mathrm{HCl}(\mathrm{pH}, 7.4), 1.5 \mathrm{~mm} \mathrm{CaCl}, 1$ mM spermidine (Serva), and the following protease inhibitors: $25 \mu \mathrm{g} /$ $\mathrm{ml}$ aprotinine, $25 \mu \mathrm{g} / \mathrm{ml}$ leupeptine, and $5 \mu \mathrm{g} / \mathrm{ml}$ pepstatin (all from
Serva). The homogenate was centrifuged $(3 \mathrm{~min}$ at $3000 \times \mathrm{g}$ ), and the pellet was resuspended in HS buffer. Myelin was separated from other membranes by centrifugation $(75,000 \times g$ for $10 \mathrm{~min})$ in a sucrose step gradient with $15 \%, 25 \%$, and $50 \%$ sucrose in the upper, middle, and lower phase, respectively. Myelin was recovered from the top of the 
$15 \%$ sucrose phase, and a fraction enriched in cell-surface membranes, from the interband of the $15 \%$ and $25 \%$ sucrose phase (modified after Colman et al., 1982).

Myelin and cell-surface membranes of the goldfish or zebrafish CNS were obtained by homogenizing tectal hemispheres or the entire brain in HS buffer and through centrifugation in a sucrose step gradient (upper phase, $20 \%$ sucrose; lower phase, $50 \%$ sucrose). Myelin was collected from the upper and membranes from the lower band (Vielmetter and Stuermer, 1989).

The fractions enriched in rat and fish myelin, as well as the fractions enriched in the other cell-surface membranes, were rinsed separately in PBS and stored at $-80^{\circ} \mathrm{C}$.

Samples of goldfish membrane and myelin fractions were prepared for electron microscopy according to standard procedures (Colman et al., 1982). As shown by the electron micrographs in Figure 1, both fractions were highly enriched in either membranes (Fig. 1a) or myelin (Fig. $1 b$ ).

Myelin stripes. Myelin (or membrane) stripes were created with the aid of a special silicone matrix (Walter et al., 1987b; Vielmetter et al., 1990). This matrix contains in its center an area with parallel bars (40 $\mu \mathrm{m}$ wide) separated by channels ( $50 \mu \mathrm{m}$ wide) and 2 broader channels perpendicular to the parallel bars and channels at both ends. The matrix was placed on a polylysine/laminin-coated coverslip, and the channels were filled with either the myelin or the membrane suspensions $(150$ $\mu \mathrm{g} / \mathrm{ml}$, determined by optical density measurements). Attachment of myelin or membrane particles to the coated glass surfacc was achicved by centrifuging them down onto the coverslip in a Minifuge $T$ (Heraeus) at $3000 \times g$ for $20 \mathrm{~min}$. After removal of the matrix, this procedure gave a patterned substrate of alternating lanes of polylysine/laminin alone next to polylysine/laminin covered with myelin or cell-surface membranes. All parallel lanes were bounded at the ends by myelin (or membranes) from the perpendicular channel of the matrix (Fig. 2). A small segment of goldfish retina was placed onto the coverslip perpendicular to the parallel lanes. Contacts of growing retinal axons with membranes or myelin were monitored with time-lapse videomicroscopy.

After 2-3d, these cultures were fixed with 2\% glutaraldehyde in PRS and postfixed in $1 \% \mathrm{OsO}_{4}$ in PBS. During this procedure, most of the membrane particles were lost from the coverslip and therefore are seen in Figure 11 in lower density than in Figurc 12. The cultures were dehydrated in a graded series of ethanol, embedded in Euparal (Roth), and photographed with phase-contrast optics (Zeiss Axiophot).

Time-lapse videomicroscopy. The encounters of growing axons with glial cells, with cell-surface membranes, or with myelin were observed at room temperature $\left(22-25^{\circ} \mathrm{C}\right.$ ) in an inverted microscope (Zeiss IM $35)$. Growth cone contacts were monitored in phase contrast using a $40 \times$ lens and an additional magnification lens of $1.6 \times$. A magnetic shutter controlled by an electronic device was inserted between the light source and the condensor and was opened every $15 \mathrm{sec}$ for $250 \mathrm{msec}$. The image was recorded by a videocamera, transferred to and stored in an image processing system (Hamamatsu DVS 3000), and recorded on a modified U-matic videorecorder (described in Allen, 1987). Single frames were photographed from the TV screen using Agfa Pan 25 film.

Quantitative growth assay. To evaluate the growth permissivity of membranes or myelin, the number of axons extending on these substrates was determined in a quantitative growth assay (Vielmetter and Stuermer, 1989). Equal amounts of membranes or myelin $(5 \mu \mathrm{g} / \mathrm{ml})$ were centrifuged onto the bottoms of 96-well dishes (Nunc). A small retinal explant $(200 \times 200 \mu \mathrm{m})$ was added to every well and kept in modified L- 15 at $23^{\circ} \mathrm{C}$. After $48 \mathrm{hr}$ in culture, the explants were fixed (4\% glutaraldehyde in phosphate buffer), and the number of axons per explant was counted using phase-contrast optics (Zeiss Axiovert).

\section{Results}

\section{Contacts of goldfish retinal axons with rat oligodendrocytes}

Contact with mammalian oligodendrocytes is known to inhibit the elongation of growth cones of various mammalian neurons (Schwab and Caroni, 1988; Fawcett et al., 1989). To determine whether goldfish retinal axons are sensitive to these inhibitory components, we monitored the response of goldfish retinal axons to contact with rat optic nerve oligodendrocytes.

Rat optic nerve oligodendrocytes identified by $\mathrm{Mab}_{\mathrm{B}}$ in living mixed glial cell cultures were of 2 types, highly branched

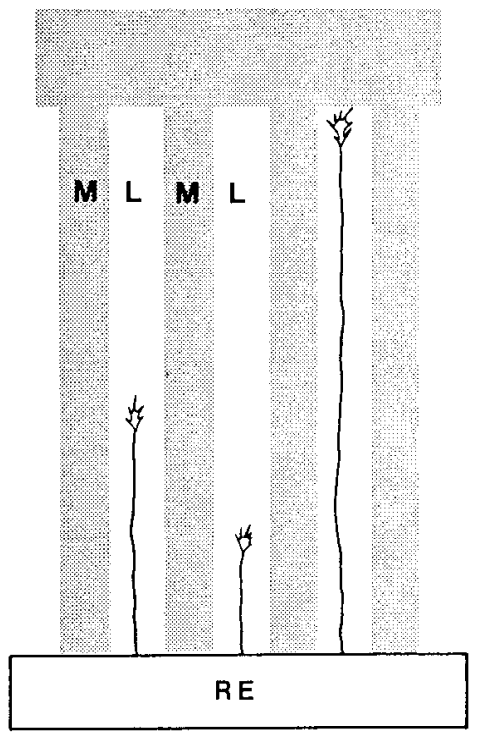

Figure 2. Schematic representation of the alternating lanes of polylysine/laminin and myelin (shaded regions). A goldfish retinal explant $(R E)$ was placed perpendicular to the parallel lanes. Retinal axons elongating on the laminin lanes $(L)$ contact and interact with the myelin $(M)$ in the lanes at their sides and in the "dead end" of the laminin lanes.

cells with an $\mathrm{O}_{1}$-positive radial process network and cells of bior multipolar morphology and only few $\mathrm{O}_{1}$-positive processes (stellate oligodendrocytes; Schwab and Caroni, 1988). Goldfish retinal explants were placed on polylysine/laminin-coated coverslips with the glial cultures stained with $\mathrm{Mab} \mathrm{O}_{1}$. The retinal explants extended the first axons $3-4 \mathrm{hr}$ after explantation. These axons elongated at a fairly constant rate of $60-80 \mu \mathrm{m} / \mathrm{hr}$. Sixtyeight encounters of goldfish retinal axons with rat glial cells were monitored. The most dramatic effect was seen when a growth cone contacted a highly branched oligodendrocyte $(N=21)$. The growth cones either collapsed or grew around these cells (see Fig. 4a), but never crossed them. Before it collapsed (Fig. $3 ; 12$ of 21 encounters), the growth cone touched and interacted with the cell. It typically extended lamellipodia onto the oligodendrocyte, continued to ruffle for $12 \mathrm{~min}$ to $2 \mathrm{hr}$, and pulled back rapidly. Unbranched axons with only 1 growth cone retracted over more than $100 \mu \mathrm{m}$ and out of the microscopic field. When bifurcated, the axonal branch that contacted the oligodendrocyte retracted back to the branch point, while the growth cone of the other branch continued to elongate. Axons that did not collapse after they met the oligodendrocyte ( 9 of 21 ) avoided crossing the cell by growing around it (Fig. 3). During its growth, the growth cone contacted the cell with part of its lamcllipodia. Both responses, growth cone collapse and avoidance by growth around the cell, were observed at the same cells. In none of these encounters did an axon manage to grow over the surface of a highly branched oligodendrocyte. Two axons grew under these cells, but in these instances, the branches of the oligodendrocyte resided on an $\mathrm{O}_{1}$-negative flat cell. Similar observations were made by Fawcett et al. (1989).

The response of goldfish retinal axons upon contact with mammalian oligodendrocytes of stellate morphology $(N=29$; Fig. $4 b$ ) was either collapse ( 8 of 29 ), avoidance (i.e., the axons grew around the cells; 11 of 29 ), or growth over (10 of 29) these cells. All 3 types of reactions were seen at the same cell.

To exclude the possibility that the antibody complex (Mab 

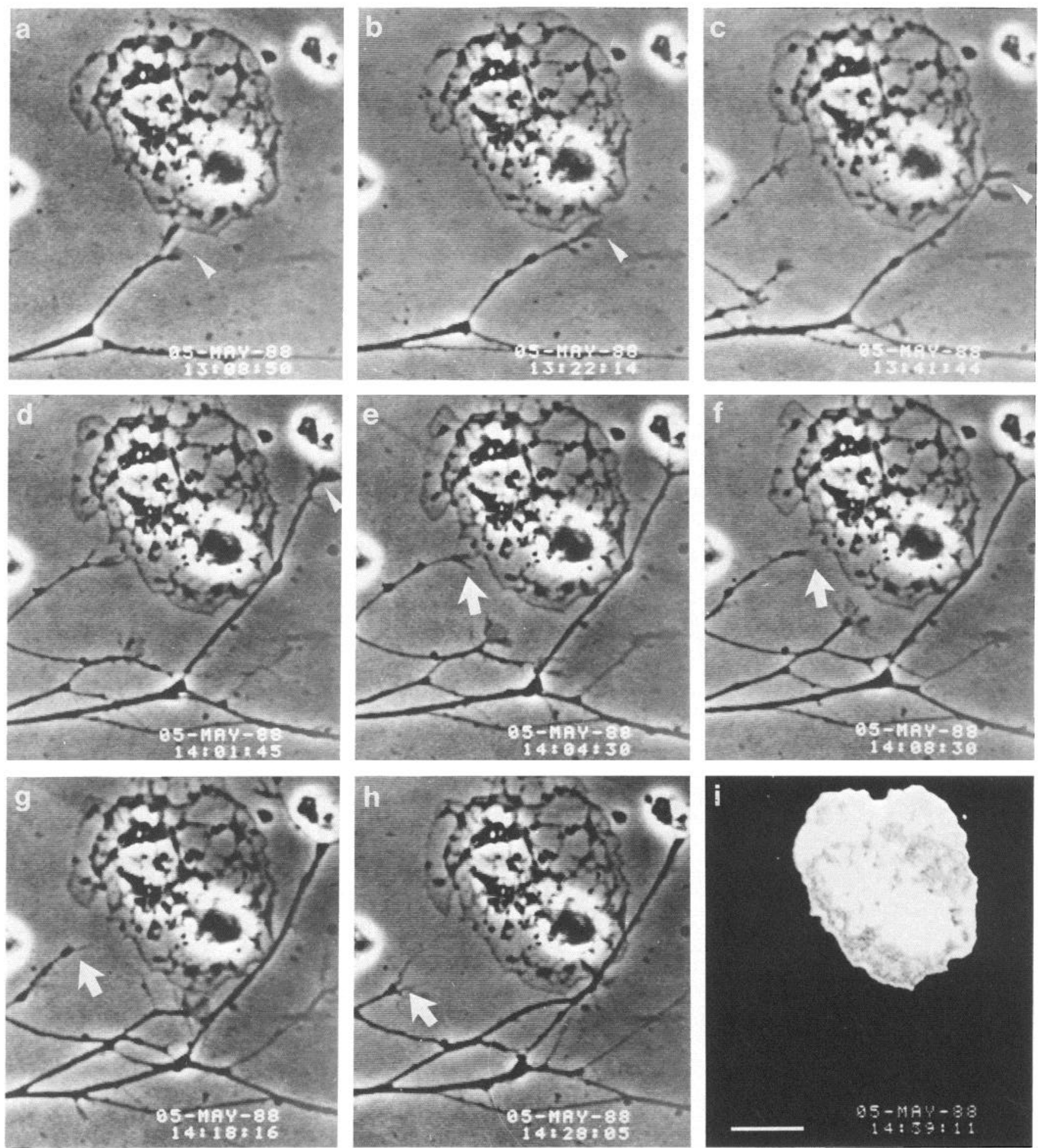

Figure 3. Sequence of time-lapse videomicrographs showing the encounter of goldfish retinal axons with a highly branched rat oligodendrocyte. One axon (arrowheads in $a-d)$ grows around the cell. The growth cone of another axon (arrow in $e$ ) contacts the cell and collapses (arrows in $f-h$ ). The oligodendrocyte was identified with $\mathrm{Mab}_{1}$ (fluorescence image in $i$ ). Time in hours, minutes, and seconds is shown in the lower right-hand corner of each frame. Scale bar, $20 \mu \mathrm{m}$ for $a-i$.

$\mathrm{O}_{1}$ and secondary antibodies) influences the growth cone responses, growth cone encounters with oligodendrocytes labeled with anti-GalC (Ranscht et al., 1982) instead of $\mathrm{O}_{1}$, and with unlabeled oligodendrocytes that were identified by morpholog- ical criteria, were recorded. After termination of the recordings, the unlabeled cells were identified with $\mathrm{O}_{1}$ antibodies. In both experiments, oligodendrocytes of highly branched morphology were avoided by the axons. 
The reactions were quite different when the axons encountered $\mathrm{O}_{1}$-negative cells of either stellate or fibroblastlike morphology (Fig. 4c). More than $90 \%$ of the axons crossed these cells freely without significantly reducing their velocity.

Thus, differentiated mammalian oligodendrocytes possess nonpermissive substrate properties for the growth of goldfish retinal axons. This in turn implies that goldfish retinal axons have a sensitivity to the inhibitory properties. $\mathrm{O}_{1}$-negative cells, in contrast, are permissive substrates for axonal growth.

Contacts of goldfish retinal axons with rat oligodendrocytes in the presence of an antibody against myelin-associated neurite growth inhibitor (IN-1)

The Mab IN-1 against the 35- and 250-kDa cell-surface components of oligodendrocytes can partially neutralize the inhibitory properties of these cells for mammalian cells and processes (Caroni and Schwab, 1988b). Io test whether collapse and the avoidance response of goldfish retinal axons are evoked by these proteins, we monitored contacts of goldfish axons $(N=9)$ and with $\mathrm{O}_{1}$-positive highly branched rat oligodendrocytes in the presence of IN-1 antibodies. Two axons collapsed, and 2 grew around the cells, but 5 axons crossed over the oligodendrocytes (Fig. 5). This clearly contrasts with the growth cone reactions to the highly branched oligodendrocytes in the absence of this antibody, and this difference is statistically significant ( $\alpha=0.01$; $\chi^{2}$ test after Brandt and Snedecor). As described above, none of the axons in the latter case were able to cross these cells (Fig. $4 a$ ). Therefore, the inhibitory properties of mammalian oligodendrocytes for goldfish retinal axons can, at least in part, be neutralized by this antibody. This indicates that goldfish retinal axons are sensitive to the same inhibitory proteins of oligodendrocytes as mammalian cells and neurites.

\section{Contacts of goldfish retinal axons with goldfish oligodendrocytes}

In 3-week-old glial cell cultures from regenerating goldfish optic nerves and tracts, more than $80 \%$ of cells were $\mathrm{Mab} \mathrm{O}_{4}$ positive. $\mathrm{Mab} \mathrm{O}_{4}$-negative cells were very rarely mixed with $\mathrm{O}_{4}$-positive cells, but rather, were found in separate groups. In double-labeling experiments with $\mathrm{Mab} \mathrm{O}_{4}$ and $6 \mathrm{D} 2$, roughly $90 \%$ of $\mathrm{O}_{4^{-}}$ positive cells were also $6 \mathrm{D} 2$ positive. Because Mab $6 \mathrm{D} 2$ is directed against fish CNS myelin-specific proteins IP1 and IP2 (Jeserich et al., 1990), the 6D2-positive glial cells of the regenerating fish optic nerve/tract may be considered to be oligodendrocytes or oligodendrocytelike cells. Figure $6 a-c$ illustrates a goldfish oligodendrocytelike cell labeled with $\mathrm{O}_{4}$ and $6 \mathrm{D} 2$. The Mab 6D2 staining was, in some cells, concentrated around the region of the nucleus and at the tips of the membranous extensions (Fig. 6c) and, in other cells, evenly distributed over the entire cell surface (Fig. $6 d$ ). The $\mathrm{O}_{4} / 6 \mathrm{D} 2$-positive cells had membranous extensions that are typical for oligodendrocytes (Fig. 6). These fish oligodendrocytelike cells increase in number over time in culture (Bastmeyer et al., 1989; V. M. Bastmeyer, unpublished observations), are at times highly motile, change their shape, and are either bi- or multipolar or flat. They simultaneously express the $\mathrm{O}_{4}$ and 6D2 antigens and GFAP (Fig. 6d,e; Bastmeyer et al., 1989). However, anti-GFAP-positive fibrils in $\mathrm{O}_{4} / 6 \mathrm{D} 2$-positive cells were considerably smaller in number than in $\mathrm{O}_{4} / 6 \mathrm{D} 2$-negative cells. Mab $\mathrm{O}_{4} / 6 \mathrm{D} 2$-negative cells in these cultures differed morphologically from $\mathrm{O}_{4} / 6 \mathrm{D} 2$-positive cells in the following respects: They were smaller, they did not possess membranous extensions, they were anti-GFAP positive (Bast-
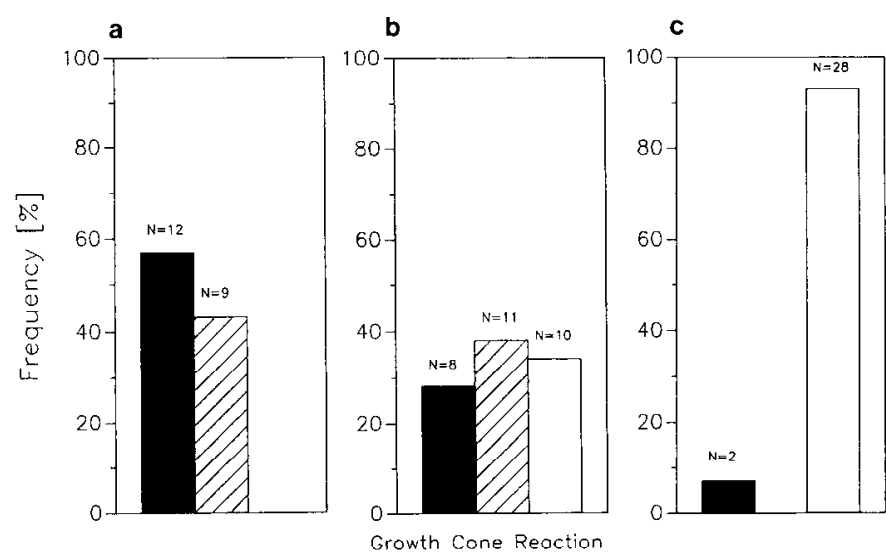

Figure 4. Frequency distribution of the 3 types of reactions that goldfish retinal axons exhibit upon contact with glial cells of the rat optic nerve. Solid bars, growth cone collapse; hatched bars, growth around the cell; open bars, growth over the cell. Types of reaction: $a$, to highly branched oligodendrocytes; $b$, to oligodendrocytes of stellate morphology; $c$, to $\mathrm{O}_{1}$-negative glial cells.

meyer et al., 1989), and they occurred in groups that lie outside of $\mathrm{O}_{4} / 6 \mathrm{D} 2$-positive cell groups.

In cocultures with goldfish retinal explants, the retinal axons were seen next to and in high density on the surface of the fish $\mathrm{O}_{4} / 6 \mathrm{D} 2$-positive oligodendrocytelike cells. Avoidance of oligodendrocytelike cells by axons, as typical in cocultures of axons and rat oligodendrocytes (Fawcett et al., 1989), was never observed in cocultures with goldfish oligodendrocytelike cells.

Contacts of retinal growth cones with individual goldfish optic nerve/tract oligodendrocytelike cells were monitored with timelapse videomicroscopy. Unlike rat oligodendrocytes, the living fish oligodendrocytelike cells did not maintain the antibody complexes of $\mathrm{Mab} \mathrm{O}_{4}$ or $6 \mathrm{D} 2$ and secondary antibody on their surface for an extended time period. Instead, when exposed to primary and secondary antibodies to identify oligodendrocytes, the living fish glial cells rapidly (within $45 \mathrm{~min}$ ) internalized the antibody complex into the cells, indicating a substantial rate of membrane turnover. However, in age-matched glial cell cultures, which were fixed within $15 \mathrm{~min}$ after exposure to $\mathrm{Mab}$ $\mathrm{O}_{4}$ and $6 \mathrm{D} 2$, the vast majority of the cells were labeled by both of these markers, excluding the groups of $\mathrm{O}_{4}$-negative cells as described. The growth cone contacts we recorded were exclusively with cells that morphologically resembled the $\mathrm{O}_{4} / 6 \mathrm{D} 2-$ positive cells. We therefore conclude that most if not all of the growth cone/glial cell contacts monitored with time-lapse videomicroscopy must have been encounters with oligodendrocytelike cells.

Irrespective of whether the cells were elongated in shape or flat with large membranous extensions, the axons grew in most cases $(N=51)$ onto and elongated on the surface of the cells, often following long cell processes (Fig. 7). Only a few growth cones $(N=6)$ grew around the cells or collapsed $(N=2$; Fig. 8 ). We have no explanation for these collapse or avoidance reactions, particularly because the cells did not differ morphologically from the ones that were crossed by axons. The frequency of these events, however, was significantly below the frequency of collapses observed when the axons interacted with rat oligodendrocytes. Collapse of growth cones was also observed in 2 instances $(2.7 \%)$ with rat $\mathrm{O}_{1}$-negative cells. These results show that oligodendrocytelike cells from goldfish optic 

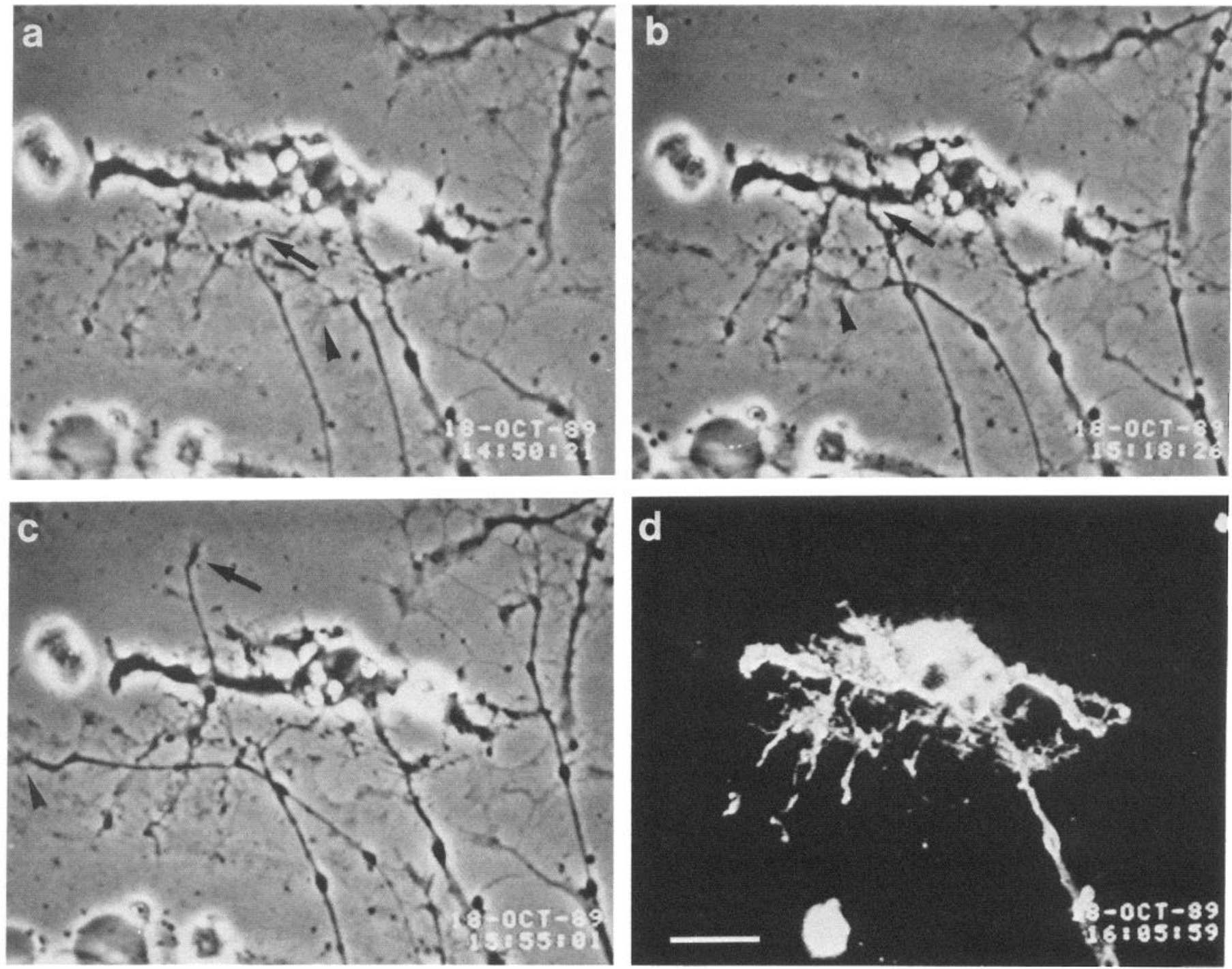

Figure 5. Contacts of goldfish retinal axons with a highly branched rat oligodendrocyte in the presence of Mab IN-1 observed with time-lapse videomicroscopy. One axon grows over the oligodendrocyte (arrows) and crosses several of its processes; the other axon, along the cell perimeter (arrowheads). The oligodendrocyte was identified with Mab $\mathrm{O}_{1}$ (fluorescence image in $d$ ). Time in hours, minutes, and seconds is shown in the lower right-hand corner of each frame. Scale bar, $20 \mu \mathrm{m}$ for $a-d$.

nerve/tract, unlike mammalian oligodendrocytes, are permissive substrates for the growth of goldfish retinal axons.

\section{Contacts of goldfish retinal axons with zebrafish oligodendrocytes}

To determine whether these properties of fish oligodendrocytes are unique to those derived from regenerating optic nerves and tracts or whether they are shared by oligodendrocytes of other regions of the fish CNS, we isolated glial cells from juvenile zebrafish brains and cocultured them with goldfish retinal axons. Juvenile zebrafish from our breeding colony were used instead of adult goldfish, because with the dissociation procedure and culture conditions used here, brains from juveniles gave a reasonable number of oligodendrocytes, whereas those of adult goldfish did not. In these cocultures, the oligodendrocytes were identified by labeling the living cells with either $6 \mathrm{D} 2$ or $\mathrm{O}_{4}$ antibodies. Cells positive for the $\mathrm{O}_{4}$ and $6 \mathrm{D} 2$ antigens were smaller than mammalian oligodendrocytes and either had long and slender processes or had large, flat membranous extrusions
(Fig. 9). They closely resembled 6D2-positive differentiated trout brain oligodendrocytes (Jeserich and Rauen, 1990). Cells were not only positive for $6 \mathrm{D} 2$ and $\mathrm{O}_{4}$, but also expressed $\mathrm{GalC}$ (Ranscht et al., 1982). Furthermore, some of these cells expressed GFAP in addition to the 6D2 and $\mathrm{O}_{4}$ antigens (Fig. 9). Only the $\mathrm{O}_{4}$ antibody was used to identify these cells in cocultures for time-lapse observations. Seventy-five axonal contacts with $\mathrm{O}_{4}$-positive zebrafish oligodendrocytes and 26 contacts with $\mathrm{O}_{4}$-negative cells were monitored.

When axons contacted oligodendrocytes with large $\mathrm{O}_{4}$-positive membranous extensions, $36 \%(N=18)$ of the axons grew over and $50 \%(N=25)$ around the cells. The growth cones of 7 axons (14\%) collapsed after contact and retracted (Fig. 10a). When axons met oligodendrocytes with long processes (Fig. 10b), most axons (84\%) grew over the cells, but 3 axons (12\%) collapsed and retracted. $\mathrm{O}_{4}$-negative cells were crossed by more than $90 \%$ of the axons $(N=24$; Fig. $10 c)$.

Zebrafish brain oligodendrocytes with large membranous extensions are apparently not good substrates for the growth of 

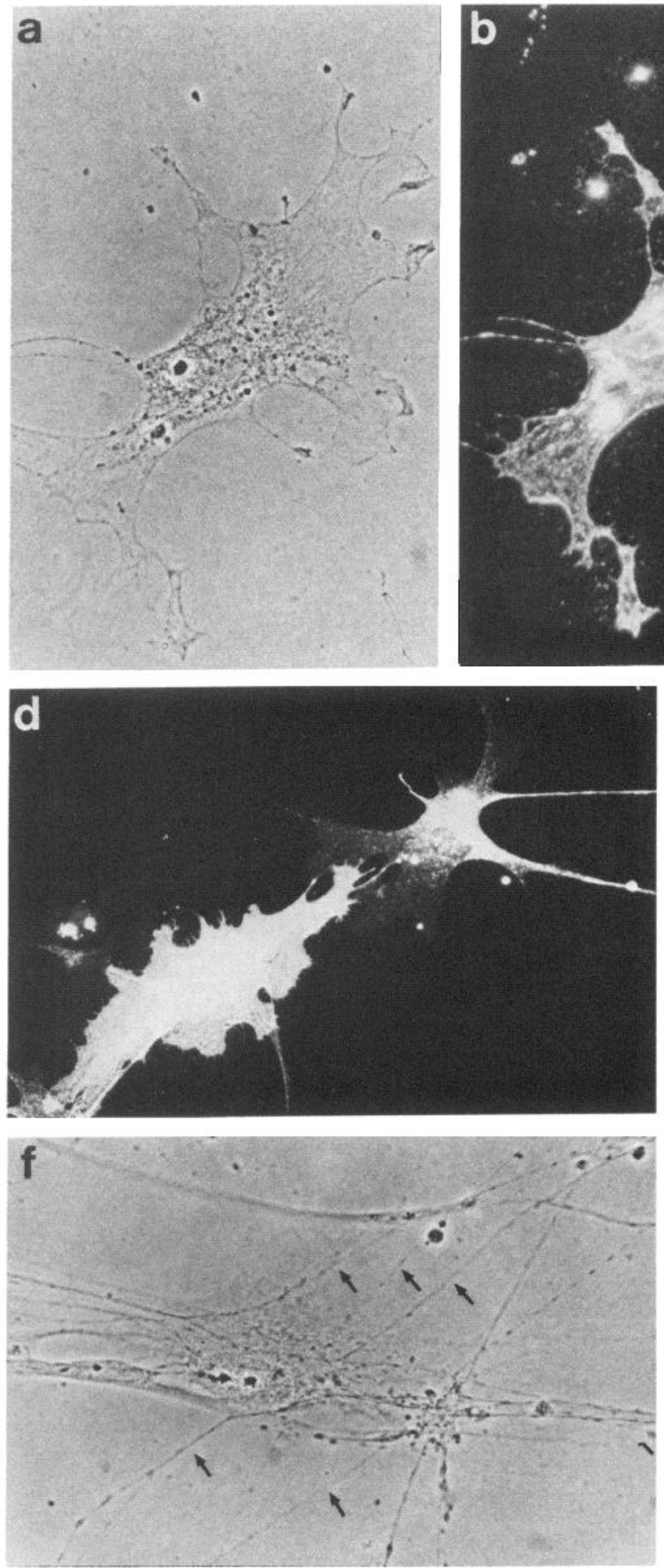
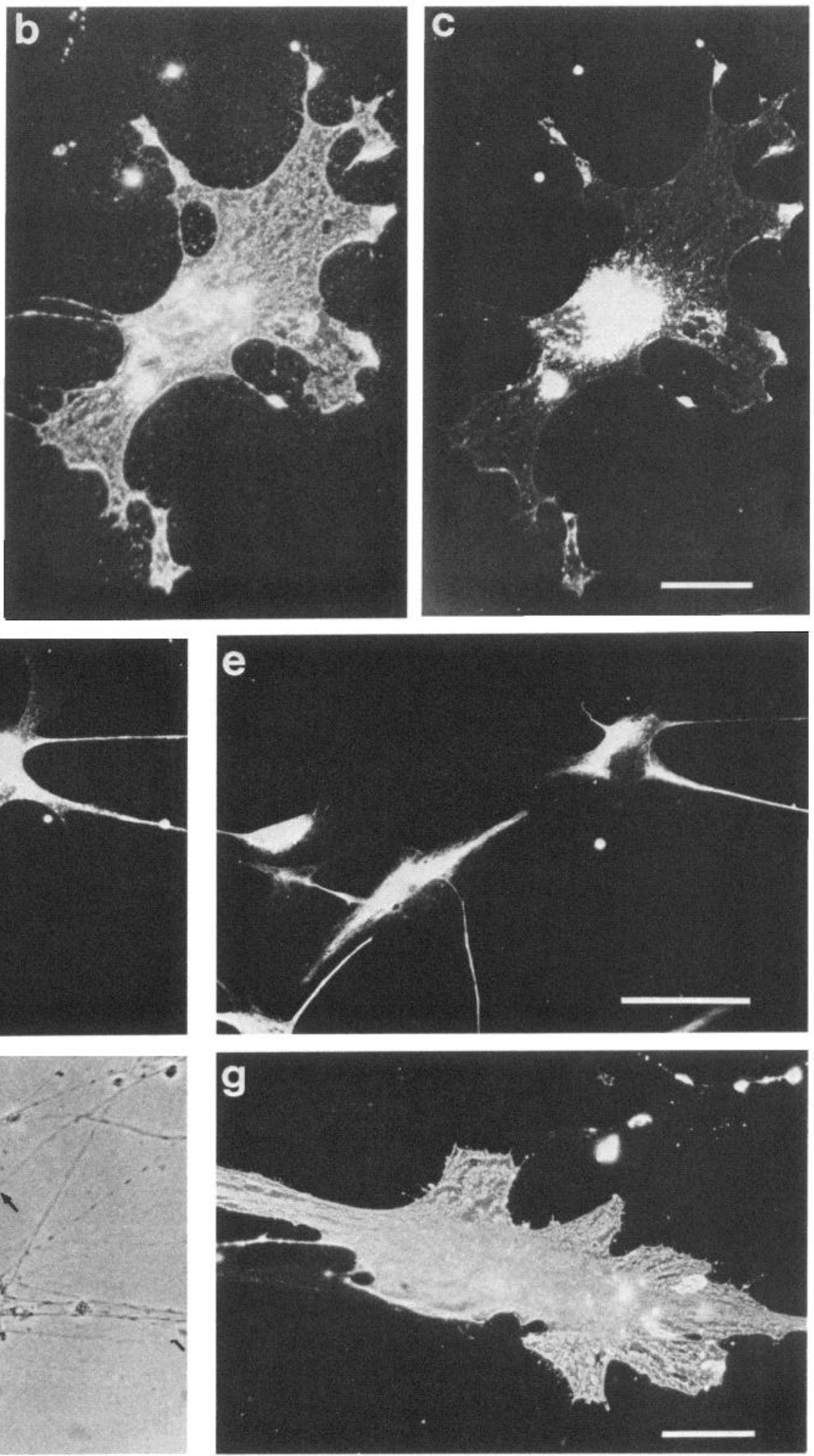

Figure 6. Goldfish optic nerve/tract oligodendrocytelike cells. $a-c$, A cell with flat morphology and membranous extensions in phase contrast. This cell is stained by $\mathrm{Mab} \mathrm{O}_{4}$ over its entire surface $(b)$ and by Mab 6D2 (c). In this cell, as in some others, Mab 6D2 staining is concentrated around the nucleus and at the tips of the membranous extensions. Scale bar, $20 \mu \mathrm{m}$ for $a-c$. $d$, Two oligodendrocytelike cells. The right cell exhibits Mab 6D2 staining over its entire surface. In the left cell, Mab 6D2 staining is concentrated near the nucleus. $e$, These 2 6D2-positive cells are simultaneously GFAP positive. Scale bar, $40 \mu \mathrm{m}$ for $d$ and $e$. $f$ and $g$, A flat Mab $\mathrm{O}_{4}$-positive oligodendrocytelike cell with membranous extensions $(g)$ is crossed by retinal axons (arrows in $f$ ). Scale bar, $40 \mu \mathrm{m}$ for $f$ and $g$. 

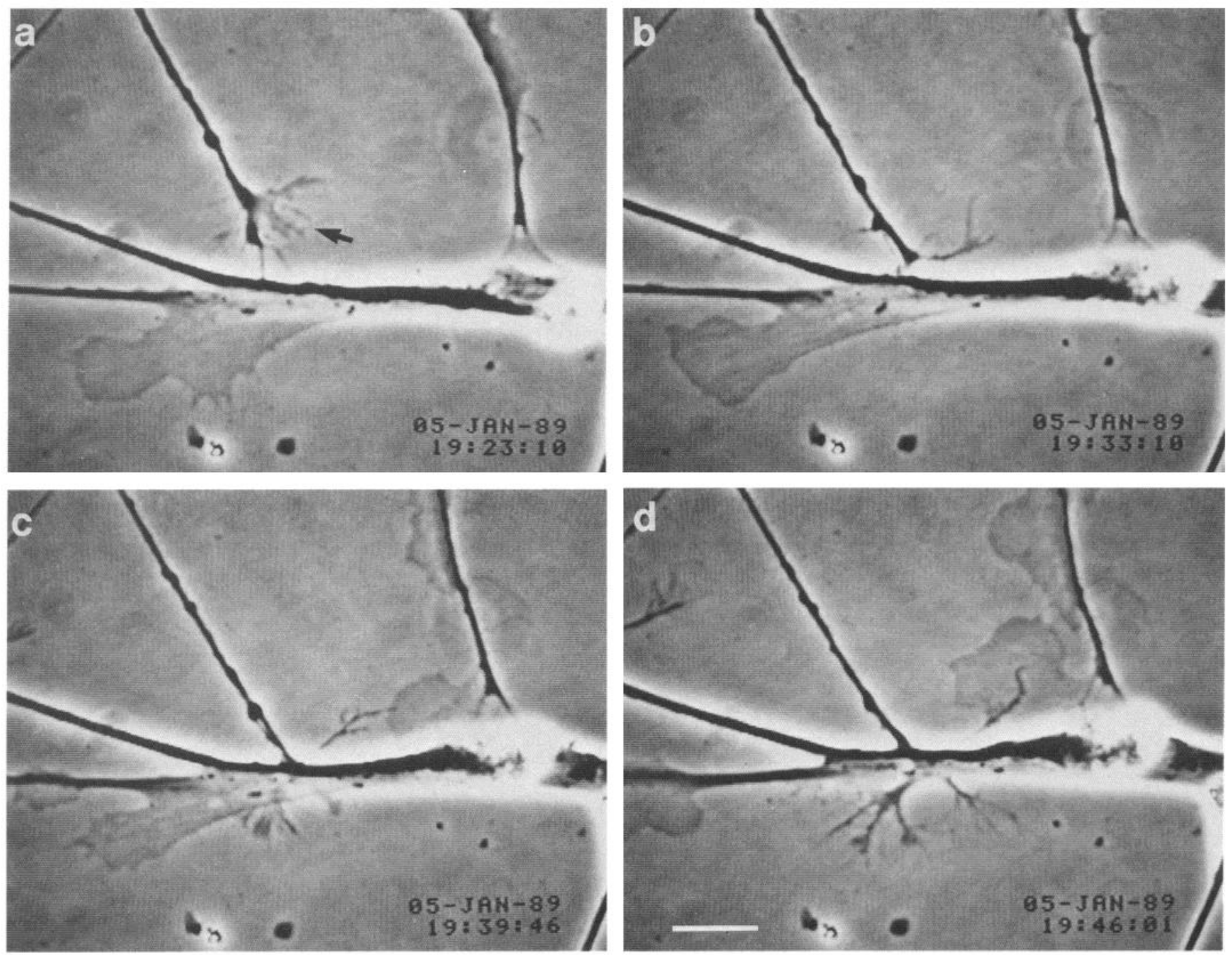

Figure 7. Sequence of videomicrographs of a goldfish retinal axon (arrow in $a$ ) encountering a goldfish oligodendrocytelike cell. The axon grows over the cell without changing its growth velocity. Time in hours, minutes, and seconds is shown in the lower right-hand corner. Scale bar, $20 \mu \mathrm{m}$ for $a-d$.

goldfish retinal axons and therefore differ from goldfish optic nerve/tract oligodendrocytelike cells. However, in comparison to reactions with mammalian oligodendrocytes, growth cone collapse was less frequent, and growth over the cells did occur. Reactions to zebrafish brain oligodendrocytes of all other morphologies did not differ significantly from those at $\mathrm{O}_{4}$-negative cells, suggesting that these oligodendrocytes are better substrates than the flat ones.

\section{Contacts of goldfish retinal axons with rat or goldfish CNS myelin}

Because myelin has the same nonpermissive substrate properties for the growth of mammalian cells and neurites as oligodendrocytes (Schwab and Caroni, 1988), we tested the interaction of goldfish axons with CNS myelin on a patterned substrate, consisting of alternating parallel lanes of myelin and polylysine/ laminin (as described in Materials and Methods; Fig. 2). Crude myelin fractions, either from spinal cords and the white matter of adult rat brains or from the brains of adult goldfish, were applied as stripes. The growth of goldfish retinal axons was evaluated in fixed cultures, $2-3 \mathrm{~d}$ after explantation of the retina and, in a few instances, with time-lapse videomicroscopy. Examples are shown in Figure 11. With rat CNS myelin in alternating lanes, the axons grew almost exclusively on the laminin lanes and rarely crossed the myelin (Fig. 11a). With goldfish CNS myelin, the axons had a slight preference for the laminin lanes. However, axons also crossed the myelin lanes or even elongated on the myelin (Fig. 11b). When membranes instead of myelin were offered as substrates in lanes, the axons crossed the patterned substrate freely.

Time-lapse videorecordings revealed an interesting behavior of goldfish retinal axons as they contacted the rat CNS myelin at the lateral borders or at the end of the polylysine/laminin lanes. As in fixed preparations, the axons avoided the myelin lanes. At the end of the lanes, where the axons were bounded by myelin on 3 sides, the growth cones either collapsed ( 3 of 15), performed U-turns and grew back into the direction of the explant (2 of 15), or grew onto the myelin (10 of 15). On myelin, they were hardly able to progress. They reduced their growth velocity of $60-80 \mu \mathrm{m} / \mathrm{hr}$ to $20 \mu \mathrm{m} / \mathrm{hr}$ and showed a previously 


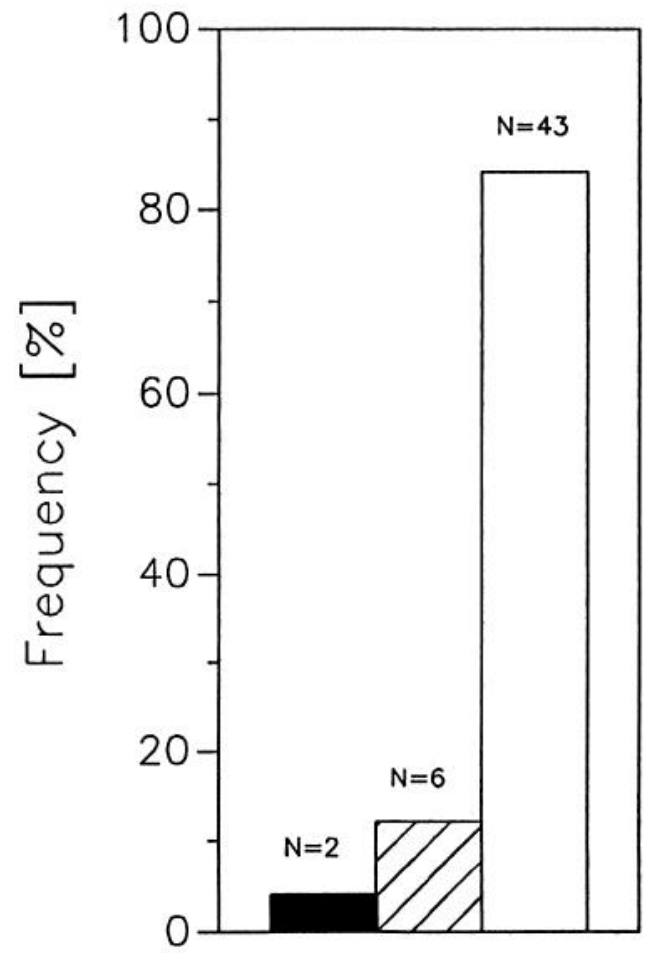

\section{Growth Cone Reaction}

Figure 8. Frequency distribution of the growth cone reactions to goldfish optic nerve/tract oligodendrocytes. Solid bar, growth cone collapse; hatched bar, growth around the cell; open bar, growth over the cell.

unseen behavior: The lamellipodia of the growth cones were very active, but did not advance (Fig. 12), giving the impression that they were unable to adhere to the substrate.

When entering into territories with goldfish CNS myelin, the axons reduced their velocity but elongated with a fairly constant rate of $40 \mu \mathrm{m} / \mathrm{hr}$. When the alternating lanes were covered with goldfish tectal membranes instead of myelin, the axons grew from the polylysine/laminin lanes freely into and over the membrane lanes without significantly changing their velocity. These observations indicate that goldfish axons are negatively affected by rat CNS myelin, because they avoid entering territories covered by CNS myelin or collapse upon contacting it. On the myelin, they are hardly able to elongate. Goldfish CNS myelin is less growth promoting than cell-surface membranes isolated from the brain and separated from the myelin fraction, but better than the CNS myelin of mammals.

\section{Quantification of axonal outgrowth on rat or goldfish CNS myelin}

The foregoing experiments indicate that rat $\mathrm{CNS}$ myelin has unfavorable substrate properties for the elongation of goldfish retinal axons. It has previously been shown that membranes that are avoided by axons in the stripe assay also reduce the outgrowth of axons from retinal explants when the membranes are offered as the sole substrate (Walter et al., 1987a; Vielmetter and Stuermer, 1989). Whether rat CNS myelin would also negatively affect the initial outgrowth of axons from the retinal explant when offered as the only substrate was investigated in this growth assay. Axons emerging from small retinal explants of defined size $(200 \times 200 \mu \mathrm{m})$ on myelin were counted after
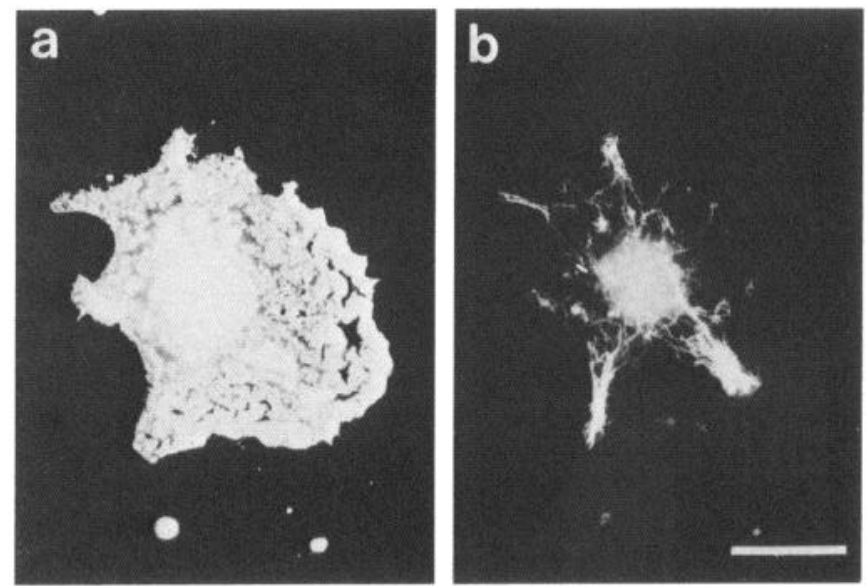

Figure 9. Zebrafish brain oligodendrocyte with flat membranous extensions. The cell is positive for $\mathrm{Mab} \mathrm{O}_{4}(a)$, but also contains GFAPpositive fibrils $(b)$. Scale bar, $20 \mu \mathrm{m}$ for $a$ and $b$.

$48 \mathrm{hr}$ in vitro. Axon numbers on rat CNS myelin were compared to axon numbers on goldfish tectal CNS myelin, on goldfish tectal membranes, and on rat brain membranes (Fig. 13).

The mean number of axons was 1.3 (SE, 0.08) on rat CNS myelin, 3.9 (SE, 0.3) on goldfish tectal myelin, 8.9 (SE, 0.9) on goldfish tectal cell-surface membranes separated from myelin (equal to earlier studies; Vielmetter and Stuermer, 1989), and 15.4 (SE, 1.6) on rat brain cell-surface membranes separated from myelin. These data show that rat brain membranes are, surprisingly, a better substrate than goldfish brain membranes. Rat CNS myelin, however, is a very poor substrate, clearly worse than goldfish myelin. Rat CNS myelin is the least supportive of all 4 substrates. Thus, both elongation and outgrowth of goldfish retinal axons are negatively affected by rat CNS myelin, but less so by fish CNS myelin.

In the above-described stripe and outgrowth assays, we used myelin and membranes derived from the goldfish tectum. To show that myelin of this source and its effect on growing axons are representative for fish CNS myelin in general, 2 additional
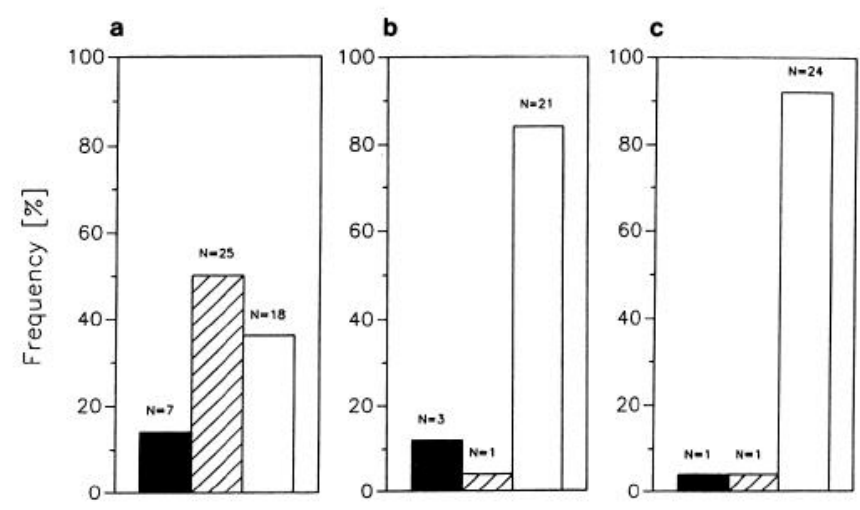

Figure 10. Frequency distribution of the reactions of goldfish retinal axons upon contact with zebrafish brain oligodendrocytes. Solid bars, growth cone collapse; hatched bars, growth around the cell; open bars, growth over the cell. Types of reaction: $a$, to oligodendrocytes with flat membranous protrusions; $b$, to oligodendrocytes of stellate morphology; $c$, to $\mathrm{O}_{1}$-negative glial cells. 

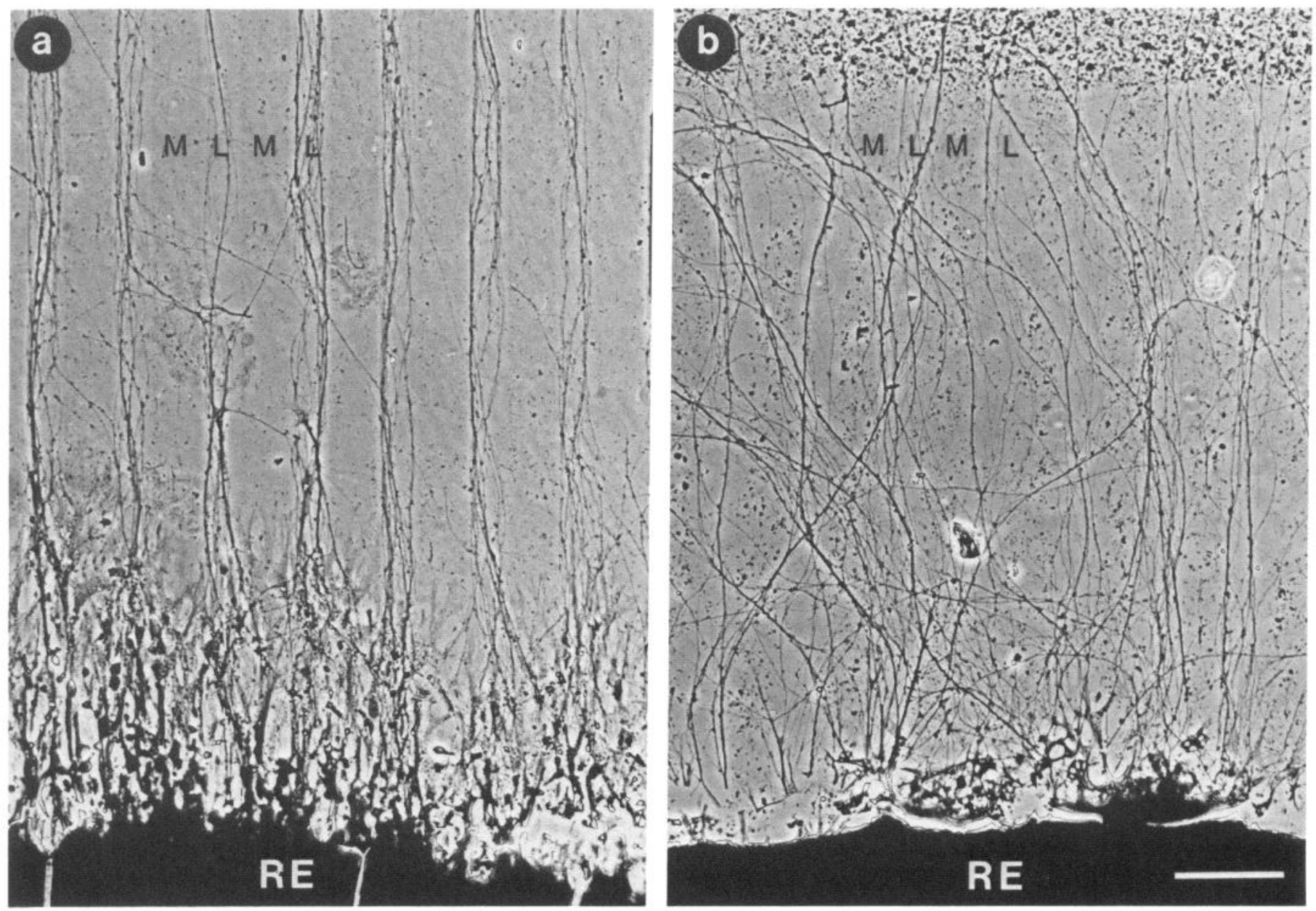

Figure 11. Phase-contrast micrographs of fixed preparations of goldfish retinal axons growing on a patterned substrate of alternating lanes of polylysine/laminin $(L)$ and lanes covered with myelin $(M)$. The retinal explants $(R E)$ are to the bottom. With rat CNS myelin, the axons grow almost exclusively on the laminin lanes $(a)$. With goldfish CNS myelin, a slight preference for the laminin is visible, but many axons cross the myelin lanes $(b)$. Scale bar, $100 \mu \mathrm{m}$ for $a$ and $b$.

outgrowth assays were performed. In the first, myelin and membranes from the entire brain of goldfish were used, and in the second, myelin and membranes of juvenile zebrafish brains. This second assay also served to clarify whether the zebrafish CNS myelin is as permissive as goldfish CNS myelin, because zebrafish brain oligodendrocytes were less supportive for axonal growth than oligodendrocytelike cells of the goldfish optic nerve/ tract.

The result of the first of these experiments shows that the number of axons on myelin of the entire goldfish brain $(4.0$; SE, $0.6)$ is equal to that on goldfish myelin from the tectum (3.9; $\mathrm{SE}, 0.3)$. Axon numbers on membranes of the entire brain were smaller $(7.0 ; \mathrm{SE}, 0.9)$ than on membranes of the tectum $(8.9$; $\mathrm{SE}, 0.3$ ), but more experiments would be required to determine whether this difference is statistically significant. Outgrowth of axons on zebrafish whole-brain myelin (3.9; SE, 0.4) turned out to be as high as on goldfish myelin of the whole brain. Axon numbers on zebrafish whole-brain membranes $(6.8 ; \mathrm{SE}, 0.8)$ were close to those found on goldfish whole-brain membranes.

The properties of CNS myelin of zebrafish and goldfish are apparently not different. These findings substantiate the conclusion that fish CNS myelin allows the growth of roughly 3 times as many axons as rat CNS myelin.

\section{Discussion}

In this study, we sought to determine whether glial cells in the fish optic nerve/tract, and in particular, the oligodendrocytes and fish CNS myelin, differ from those in mammals (Schwab and Caroni, 1988) in relation to their inhibitory properties for regrowing axons. Such a difference might explain the difference between fish and mammalian CNS axons in their ability to regenerate.

We have found that goldfish retinal axons are sensitive to the nonpermissive substrate properties of rat optic nerve oligodendrocytes and CNS myelin. Such unfavorable properties are not possessed by oligodendrocytelike cells of the goldfish optic nerve/ tract and fish CNS myelin. These conclusions are based upon observations of the reaction of growing retinal axons to the glial cells and myelin in in vitro assays. Upon contact with rat optic nerve oligodendrocytes, goldfish retinal growth cones collapse and retract or grow around but not over these cells. However, axons grow over and even elongate on the surfaces of goldfish oligodendrocytelike cells of the optic nerve/tract. Axons avoid territories covered by rat CNS myelin, which appears to interfere with growth cone attachment and which hinders outgrowth of axons from retinal explants. Fish CNS myelin, in contrast, is 

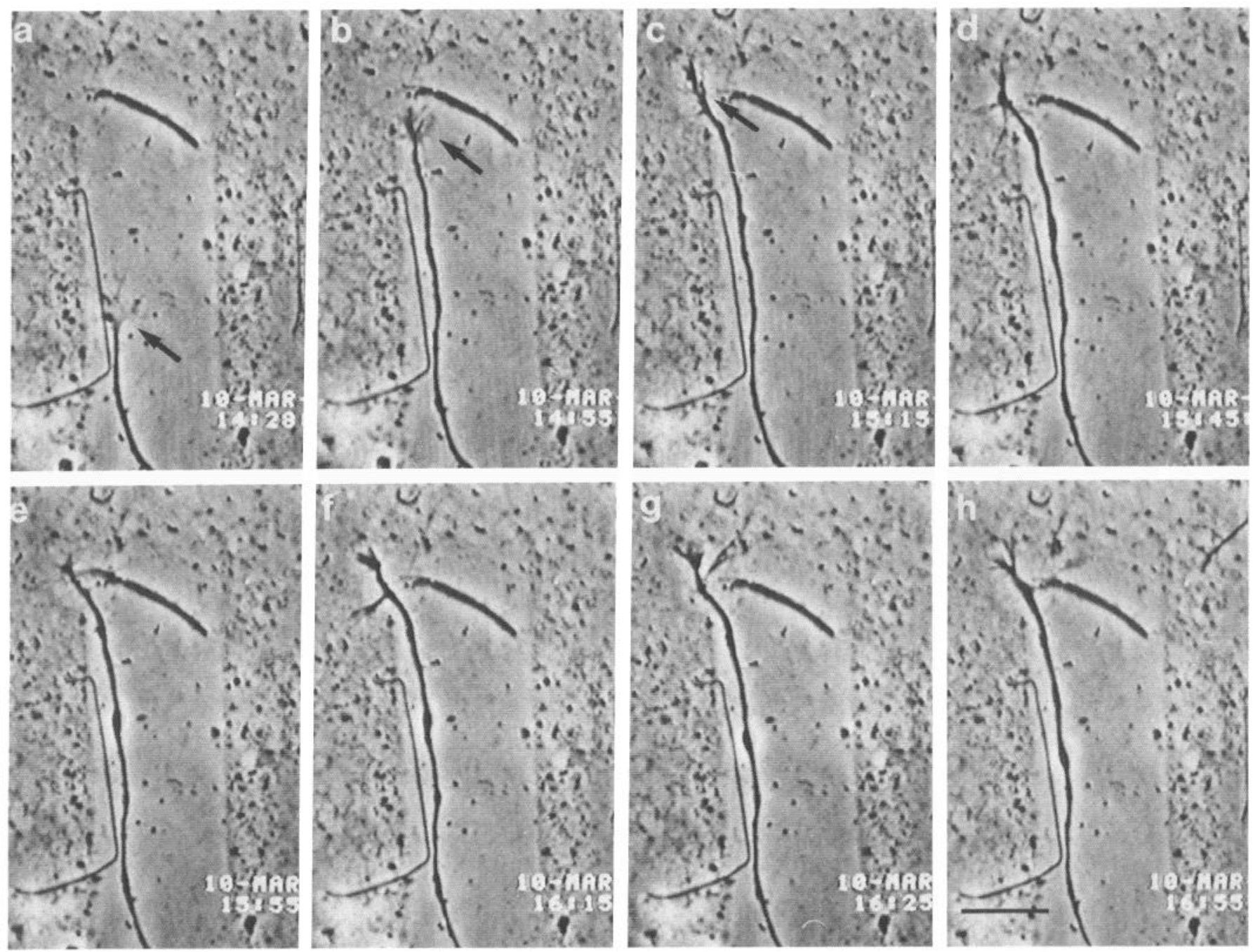

Figure 12. Sequence of videomicrographs of a small fascicle of axons with joined growth cones growing on a patterned substrate of laminin and rat CNS myelin. The growth cones elongate on the laminin (arrows in $a-c$ ). On the myelin, the growth cones are active, but are unable to progress $(c-h)$. Time in hours and minutes is shown in the lower right-hand corner. Scale bar, $20 \mu \mathrm{m}$ for $a-h$.

growth permissive, is crossed by retinal axons, and allows substantial axonal outgrowth from explants. Thus, the view that the environment of a damaged axon contributes to success or failure of axonal regeneration also holds for fish retinal axons.

\section{Goldfish retinal axons are sensitive to the inhibitory properties of rat nerve oligodendrocytes}

Our recent success in isolating and culturing goldfish optic nerve/ tract oligodendrocytes (Bastmeyer et al., 1989) enabled us to observe the encounter of goldfish retinal axons with these cells in vitro and to compare the reaction of fish retinal axons to fish optic nerve/tract oligodendrocytelike cells with their reaction to mammalian oligodendrocytes and other glial cells. The failure of retinal axons in the mammalian optic nerve to regenerate has been shown to be due to unfavorable substrate properties of this nerve, with one known component being 2 identified inhibitory proteins on oligodendrocytes and CNS myelin (Caroni and Schwab, 1988a). These 2 proteins are absent from the PNS (Caroni and Schwab, 1988a), where Schwann cells myelinate the axons and promote axonal regrowth after axonal injury (Ard et al., 1987).

The reactions of fish axons to contact with mature rat optic nerve oligodendrocytes, namely, collapse or a failure to cross these cells, resemble closely those shown by dorsal root ganglion (DRG) neurons encountering these cells (Fawcett et al., 1989; Bandtlow et al., 1990). These reactions indicate that goldfish retinal axons, like rat DRG axons, are sensitive to the unfavorable substrate properties of these cells. With a few exceptions, the other mammalian glial cells in the culture did not elicit collapse or avoidance and were almost always crossed by the axons. Thus, goldfish axons are not negatively influenced by glial cells of mammals in general. Indeed, goldfish axons grow vigorously on rat astrocyte monolayers (C. A. O. Stuermer, unpublished observations).

Therefore, collapse and avoidance of fish retinal axons upon contact with mammalian oligodendrocytes are likely to be due to special properties of these cells rather than reflecting a general incompatibility between fish and mammalian neuronal tissue. We found that goldfish axons are able to cross highly branched oligodendrocytes more frequently in the presence of the antibody IN-1, which partially neutralizes the inhibitory properties of the oligodendrocytes (Caroni and Schwab, 1988b). This suggests that the same proteins that inhibit mammalian axons are also responsible for the reaction of fish axons. This finding is 


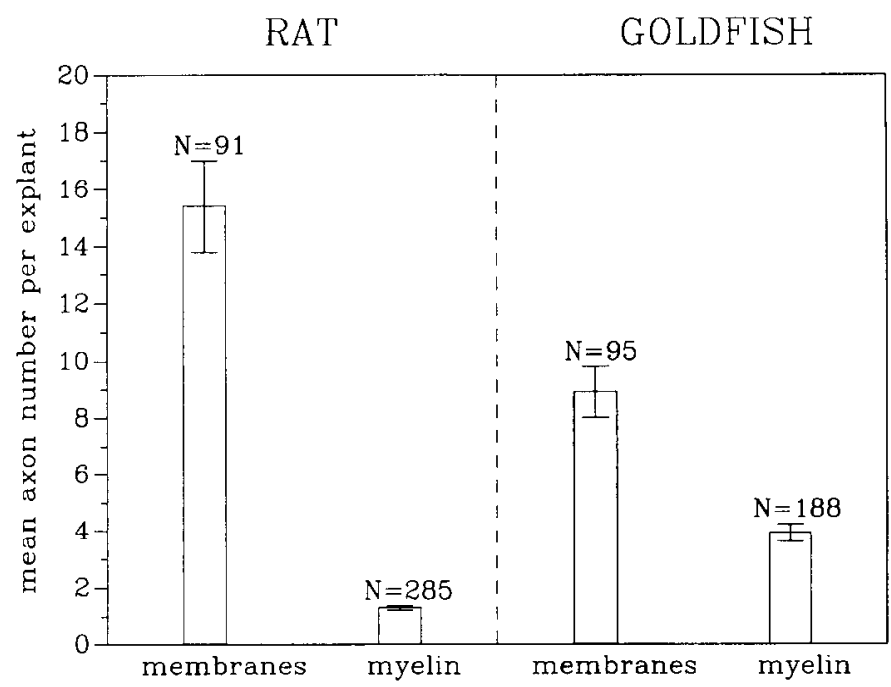

Figure 13. Outgrowth assay: histograms of numbers of axons emerging from small goldfish retinal explants on rat CNS myelin or cell-surface membranes and on goldfish tectal myelin or tectal cell-surface membranes. Error bars in each column represent SE.

surprising because these proteins are apparently not present in fish CNS myelin (Caroni and Schwab, 1988a). Possible explanations are that these or related proteins are expressed on other ncuronal or non-ncuronal cells in the fish CNS or that their concentration is below detection level. Alternatively, the fish may possess related but different proteins that are not detected by previous methods.

Another molecule that repulses retinal axons is the cell-surface-associated component on caudal tectal membranes of the embryonic chick (Walter et al., 1987a) and adult fish (Vielmetter and Stuermer, 1989). This component predominantly affects the temporal retinal axons and has little effect on nasal axons. The oligodendrocyte and CNS myelin-associated inhibitors, however, exert their influence on both temporal and nasal fish axons to the same degree. Furthermore, temporal axons in chick and fish are able to grow on caudal tectal membranes if they are exposed solely to caudal membranes and not given a choice between rostral and caudal membranes (Walter et al., 1987a,b; Vielmetter and Stuermer, 1989). These observations and preliminary data on the molecular nature of this repellent component (F. Bonhoeffer, unpublished observations) suggest that the mammalian oligodendrocyte inhibitory proteins are different from the caudal tectal repellant component.

\section{Fish oligodendrocytelike cells}

Unlike rat optic nerve oligodendrocytes, the oligodendrocytelike cells of the regenerating fish optic nerve/tract are not inhibitory to growing retinal axons, but rather, are growth permissive (Bastmeyer et al., 1990). The fish oligodendrocytelike cells differ from the oligodendrocytes of the rat optic nerve, in that they divide in culture and acquire various shapes. However, they always have membranous extensions typical of oligodendrocytes and express myelin markers.

Fish oligodendrocytelike cells express the same $\mathrm{Mab} \mathrm{O}_{4}$ antigen that mammalian glial cells of the O-2A lineage begin to exhibit prior to their differentiation into mature oligodendrocytes (Raff et al., 1983; Trotter and Schachner, 1989). When mammalian oligodendrocytes mature, they express, in addition to the $\mathrm{O}_{4}$ antigen, the myelin marker $\mathrm{GalC}$ and myelin basic protein (MBP; Gard and Pfeiffer, 1989). Up to now, we have not found an antibody against MBP that cross-reacts with fish myelin. However, $\mathrm{O}_{4}$-positive fish glial cells are positive for $\mathrm{Mab}$ 6D2 directed against 2 identified fish myelin proteins, IPI and IP2 (Jeserich and Waehneldt, 1986). This indicates that the $\mathrm{O}_{4}$ ' 6D2-positive fish glial cells are oligodendrocytelike cells. Whether the fish optic nerve, like the rat optic nerve, has progenitors for type 2 astrocytes and oligodendrocytes remains to be seen.

In contrast to $\mathrm{O}_{4^{-}}, \mathrm{MBP}$-, and GalC-positive mammalian glial cells, $\mathrm{O}_{4} / 6 \mathrm{D} 2$-positive fish cells simultaneously express these myelin markers and GFAP. It is not known whether $\mathrm{O}_{4} / 6 \mathrm{D} 2 /$ GFAP-positive glial cells cease expressing GFAP on further maturation. Changing the culture conditions and depriving the cells of FCS (M. Bastmeyer and C. A. O. Stuermer, unpublished observations) fail to prevent the oligodendrocytelike cells from expressing GFAP. However, $\mathrm{O}_{4} / 6 \mathrm{D} 2$-positive cells always expressed less GFAP than $\mathrm{O}_{4} / 6 \mathrm{D} 2$-negative cells. Furthermore, even zebrafish brain $\mathrm{O}_{4}^{-}, 6 \mathrm{D} 2-$, and GalC-positive oligodendrocytes, which resemble more closely mature $\left(\mathrm{O}_{4^{-}}, \mathrm{GalC}-\right.$, and MBP-positive) mammalian oligodendrocytes, express GFAP. We intend to investigate the antigen expression pattern in fish oligodendrocytelike cells in vivo and in vitro when they myelinate axons.

Because inhibition is only exerted on axons by mature mammalian oligodendrocytes, it may be argued that, under our culture conditions, goldfish oligodendrocytelike cells remain in an immature state and, if fully mature, acquire inhibitory properties like mammalian oligodendrocytes. This, however, is unlikely, because a product of mature fish oligodendrocytes, fish CNS myelin, is not growth inhibiting, whereas mammalian CNS myelin is. This is consistent with earlier results by Caroni and Schwab (1988a), who applied biochemical techniques for the isolation of the inhibitory proteins from myelin and did not find them in fish and frog CNS myelin.

It is noteworthy that oligodendrocytes isolated from juvenile zebrafish brains caused growth cone collapse more frequently (14\% of encounters) than goldfish optic nerve/tract oligodendrocytes ( $4 \%$ of encounters). Growing around instead of over the cells was also seen more often with zebrafish oligodendrocytes than with those of the goldfish optic nerve/tract. However, it is unclear why zebrafish brain myelin is as growth permissive as that from goldfish brains. Glial cells from the optic nerve/ tract may be different from glial cells of other parts of the brain, or lesions such as optic nerve cut may induce the proliferation of growth-supporting glial cells. Little is known about the success or failure of regeneration of other axon tracts in the fish CNS and the role played by glial cells.

\section{Mammalian CNS myelin is nonpermissive for the growth of goldfish retinal axons}

Mammalian CNS myelin has been the source for the isolation and characterization of the 2 inhibitory proteins of 35 and 250 $\mathrm{kDa}$ (Caroni and Schwab, 1988a). Therefore, it is not surprising that rat CNS myelin, like oligodendrocytes, has unfavorable substrate properties for the growth of fish retinal axons as well. Rat myelin as a substrate hindered axonal outgrowth from retinal explants. Furthermore, in our modified stripe/choice assay, axons grew almost exclusively in lanes that had not been covered by CNS myelin. Direct confrontations with myelin in the "dead end" of the lane led, in some instances, to growth cone collapse and retraction. Occasionally, axons managed to grow onto the 
myelin, but significant progression of the growth cone was not observed. Degradation of some of the inhibitory proteins may explain why growth in to the myelin was possible for some axons, and why growth cone collapse was observed only occasionally. The behavior of the axons in the choice assay could reflect either the inability of the growth cones to adhere due to the lack of adhesive components or their reaction to the remaining activity of the inhibitory proteins.

\section{Growth permissivity of fish CNS myelin}

The properties of goldfish CNS myelin are different from rat CNS myclin, as judged by the number of goldfish axons that are able to cross myelin stripes and to grow out from explants residing on a myelin carpet as a substrate. That goldfish CNS myelin is more permissive than myelin of the mammalian CNS has been shown not only for goldfish retinal axons, but also for regenerating rat retinal axons in culture (Vanselow et al., 1990). On the other hand, goldfish CNS myelin is less growth supportive than CNS cell-surface membranes depleted of myelin. On those membranes, axons extended readily and did not discriminate between membranes and polylysine/laminin-covered glass surfaces in the modified stripe assay. Laminin has been shown to be one of the best substrates for goldfish retinal axons among the substrates tested so far (Vielmetter et al., 1990). Cell membranes probably express a number of growth-promoting molecules, and myelin may lack these or express them to a much lesser extent. Nonetheless, goldfish CNS myelin has more favorable substrate properties than mammalian CNS myelin. Extrapolated to the situation in vivo, it appears justified to conclude that goldfish myelin does not interfere with regeneration of goldfish axons. The evidence from our current in vitro experiments supports, in fact, such statements of various publications dealing with axonal regeneration in fish (Kiernan, 1979). However, direct evidence had not been offered previously.

Successful regeneration not only requires the absence of growthinhibiting molecules, but also the presence of substrates and factors with growth-promoting activities (So and Aguayo, 1985; Berry et al., 1988; Kleitman et al., 1988). Preliminary results from ongoing experiments lead us to believe that goldfish optic nerve/tract oligodendrocytelike cells are, like immature astrocytes and Schwann cells (Baehr and Bunge, 1989), highly growth promoting (Bastmeyer et al., 1990).

\section{References}

Allen TD (1987) Time lapse video microscopy using an animation control unit. J Microsc 147:129-135.

Ard MD, Bunge RP, Bunge MB (1987) Comparison of the Schwann cell surface and Schwann cell extracellular matrix as promotors of neurite growth. J Neurocytol 16:539-555.

Baehr M, Bunge RP (1989) Functional status influences the ability of Schwann cells to support adult retinal ganglion cell survival and axonal regrowth. Exp Neurol 106:27-40.

Bandtlow C, Zachleder T, Schwab ME (1990) Oligodendrocytes arrest neurite growth by conlact inhibition. $J$ Neurosci, in press.

Bastmeyer M, Vielmetter J, Schwab ME, Stuermer CAO (1988) Encounter of goldfish retinal axons with rat CNS-myelin and oligodendrocytes. Soc Neurosci Abstr 14:452.

Bastmeyer M, Beckmann M, Nona SM, Cronly-Dillon JR, Stuermer CAO (1989) Identification of astrocyte- and oligodendrocyte-like cells of goldfish optic nerves in culture. Neurosci Lett 101:127-132.

Bastmeyer M, Vielmetter J, Jeserich G, Stuermer CAO (1990) Growth of retinal axons on goldfish optic nerve oligodendrocytes in vitro. Soc Neurosci Abstr 16:1006.

Beckmann M, Bastmeyer M, Stuermer CAO (1989) Interaction of goldfish retinal axons with fish oligodendrocytes in vitro. Soc Neurosci Abstr 15:331.

Berry M, Hall S, Follows R, Rees L, Gregson N, Sievers J (1988) Response of axons and glia at the site of anastomosis between the optic nerve and cellular or acellular sciatic nerve grafts. J Neurocytol 17:727-744.

Caroni P, Schwab ME (1988a) Two membrane protein fractions from rat central myelin with inhibitory properties for neurite growth and fibroblast spreading. J Cell Biol 106:1281-1288.

Caroni P, Schwab ME (1988b) Antibody against myelin-associated inhibitor of neurite growth neutralizes nonpermissive substrate properties of CNS white matter. Neuron 1:85-96.

Colman DR, Kreibich G, Frey AB, Sabatini DD (1982) Synthesis and incorporation of myelin polypeptides into CNS myelin. J Cell Biol 95:598-608.

Fawcett JW, Rokos J, Bakst I (1989) Oligodendrocytes repel axons and cause axonal growth cone collapse. J Cell Sci 92:93-100.

Gard AL, Pfeiffer SE (1989) Oligodendrocyte progenitors isolated directly from developing telencephalon at a specific phenotypic stage: myelinogenic potential in a defined environment. Development 106: 119-132.

Gaze RM (1970) The formation of nerve connections. London: Academic.

Jeserich G, Rauen T (1990) Cell cultures enriched in oligodendrocytes from the central nervous system of trout in terms of phenotypic expression exibit parallels with cultured rat Schwann cells. Glia 3: 65-74.

Jeserich G, Waehneldt TV (1986) Characterization of antibodies against major fish CNS myelin proteins: immunoblot analysis and immunohistochemical localization of $36 \mathrm{~K}$ and IP2 proteins in trout nerve tissue. J Neurosci Res 15:147-158.

Jeserich G, Rauen T, Stratmann A (1990) Myelin and myelin-forming cells in the brain of fish-a cell culture approach. In: Cellular and molecular biology of myelination (Jeserich G, Althaus $\mathrm{HH}$, Waehneldt TV, eds), pp 343-359. Berlin: Springer.

Kiernan JA (1979) Hypotheses concerned with axonal regeneration in the mammalian nervous system. Biol Rev 54:155-197.

Kleitman N, Wood P, Johnson MI, Bunge RP (1988) Schwann cell surfaces but not extracellular matrix organized by Schwann cells support neurite outgrowth from embryonic rat retina. J Neurosci 8:653663.

Nona SN, Shehab SAS, Stafford CA, Cronly-Dillon JR (1989) Glial fibrillary acidic protein (GFAP) from goldfish: its localization in visual pathway. Glia 2:189-200.

Raff MC, Miller RH, Noble M (1983) A glial progenitor cell that develops in vitro into an astrocyte or an oligodendrocyte depending on the culture medium. Nature 303:390-396.

Ranscht B, Clapshaw PA, Price J, Noble M, Seifert W (1982) Development of oligodendrocytes and Schwann cells studied with a monoclonal antibody against galactocerebroside. Proc Natl Acad Sci USA 79:2709-2713.

Schwab ME, Caroni P (1988) Oligodendrocytes and CNS myelin are nonpermissive substrates for neurite growth and fibroblast spreading in vitro. J Neurosci 8:2381-2393.

So K-F, Aguayo AJ (1985) Lengthy regrowth of cut axons from ganglion cells after peripheral nerve transplantation into the retina of adult rats. Brain Res 328:349-354.

Sommer I, Schachner M (1981) Monoclonal antibodies $\left(\mathrm{O}_{1}\right.$ to $\left.\mathrm{O}_{4}\right)$ to oligodendrocyte cell surfaces: an immunocytological study in the central nervous system. Dev Biol 83:311-327.

Stuermer CAO (1991) Axonal pathfinding and target recognition of retinal axons in fish during development and regeneration. In: The development of the visual system (Lam D, Shatz CJ, Wiesel T, eds), in press. Cambridge, MA: MIT Press.

Thanus S, Baehr M, Barde YA, Vanselow J (1989) Survival and axonal elongation of adult rat retinal ganglion cells: in vitro effects of lesioned sciatic nerve and brain-derived neurotrophic factor (BDNF). Eur J Neurosci 1:19-26.

Trotter J, Schachner M (1989) Cells positive for the $\mathrm{O}_{4}$ surface antigen isolated by cell sorting are able to differentiate into astrocytes or oligodendrocytes. Dev Brain Res 46:115-122.

Vanselow J, Schwab ME, Thanos S (1990) Responses of regenerating rat retinal ganglion cell axons to contacts with central nervous myelin in vitro. Eur J Neurosci 2:121-125.

Vielmetter J, Stuermer CAO (1989) Goldfish retinal axons respond 
to position-specific properties of tectal cell membranes in vitro. Neuron 2:1331-1339.

Vielmetter J, Stolze B, Bonhoeffer F, Stuermer CAO (1990) In vitro assay to test differential substrate affinities of growing axons and migrating cells. Exp Brain Res 81:283-287.

Walter J, Kern-Veits B, Huf J, Stolze B, Bonhoeffer F (1987a) Recognition of position-specific properties of tectal cell membranes by retinal axons in vitro. Development 101:685-696.
Walter J, Henke-Fahle S, Bonhoeffer F (1987b) Avoidance of posterior tectal membranes by temporal retinal axons. Development 101:909_ 913.

Wolburg H, Bouzehouane U (1986) Comparison of the glial investment of normal and regenerating fibre bundles in the optic nerve and optic tectum of the goldfish and the crucian carp. Cell Tissue Res 244:187-192. 